\title{
A NOTE ON INTEGRAL VORTEX STRENGTH
}

\author{
VÁCLAV KOLÁR̆
}

Institute of Hydrodynamics, Academy of Sciences of the Czech Republic, 16612 Prague 6, Czech Republic; Phone: +420-233109095, Fax: +420-233324361, Mailto: kolar@ih.cas.cz

Controversial aspects of the conventional and widely used concept of the integral vortex strength are briefly discussed. The strength of a vortex is usually calculated as the circulation along the vortex boundary, or equivalently due to Green's theorem, as the surface integral of vorticity over the planar vortex cross section. However, the local effect of an arbitrary "superimposed shear" is fully absorbed by vorticity what makes the circulation a shear-biased vortex characteristic. The present paper shows that different vortexstrength models can be derived on the basis of different local vortex intensities proposed in the literature. The outcome of these models naturally differs, even for an ideally axisymmetric vortex. Three different vortex-strength models are compared and discussed by examining the unsteady Taylor vortex.

KEY WORDS: Circulation, Unsteady Taylor Vortex, Vortex Intensity, Vortex Strength, Vorticity, Vorticity Decomposition.

Václav Kolář: POZNÁMKA O INTEGRÁLNÍ SÍLE VÍRU. J. Hydrol. Hydromech., 58, 2010, 1; 8 lit., 2 obr.

V práci jsou stručně diskutovány sporné stránky konvenčního a široce užívaného pojetí integrální síly víru. Síla víru je obvykle počítána jako cirkulace podél hranice víru nebo ekvivalentně podle Greenovy věty jako plošný integrál viŕivosti přes příčný rovinný řez vírem. Lokální efekt libovolného "superponovaného smyku" je však plně absorbován viřivostí, což činí z cirkulace smykově zkreslenou vírovou charakteristiku. Tento článek ukazuje, že lze odvodit různé modely síly víru na základě různých lokálních intenzit víru navržených $\mathrm{v}$ odborné literatuře. Výsledky těchto modelů se přirozeně liší, dokonce i pro ideálně osově symetrický vír. Na podkladě zkoumání nestacionárního Taylorova víru jsou porovnány a diskutovány tř̀i různé modely síly víru.

KLÍČOVÁ SLOVA: cirkulace, nestacionární Taylorův vír, intenzita víru, síla víru, viŕivost, rozklad viŕivosti.

\section{Introduction}

The concept of the strength of a vortex tube circulation $\Gamma-$ is closely associated with Helmholtz's theorems and Kelvin's circulation theorem in basic fluid mechanics (Batchelor, 1967; Panton, 1984; Saffman, 1992; Green, 1995). Recall that a vortex tube is the set of all vortex lines passing through a simply-connected surface in space and a vortex line is everywhere tangent to the local vorticity vector. The concept of vortex strength as the circulation along the vortex boundary is widely employed to characterize the initial state, evolution, and decay of large-scale vortical structures. Here, the meaning of the term "vortex" and "vortical structure" is more general and not necessarily coinciding with a vortex tube (as defined above). Due to
Green's theorem, vortex strength is frequently determined as the surface integral of vorticity over the planar vortex cross section. The weak point of this well-established and widely used concept is that vorticity does not represent a true local vortex intensity. The controversy is caused by the wellknown fact that vorticity cannot distinguish the effect of a "background shearing" from the "actual swirling motion of a vortex" (note that one obtains a net circulation for the region of a simple shear due to a net vorticity). Vorticity is always a more or less shear-biased local intensity of the actual swirling motion of a vortex. Consequently, the circulation along the vortex boundary is always a more or less shear-biased integral vortex strength. Moreover, the vortex circulation is dependent on the vortex-boundary definition adopted. 
In the next two sections, it is shown, for simplicity in $2 \mathrm{D}$, that different vortex-strength models can be derived on the basis of different local vortex intensities. Three different vortex-strength schemes are considered: conventional vorticity-based circulation, circulation based on the so-called residual vorticity (Kolár , 2007), and the integral of the local swirling-strength parameter (Zhou et al., 1999). The first two schemes are applied to the unsteady Taylor vortex for which they are easily analytically treatable. It is further shown that they provide natural bounds (upper and lower estimates) for the third scheme based on the local swirling-strength parameter.

\section{Vortex-strength models}

For an arbitrarily chosen vortex-intensity concept the vortex cross section is generally defined in Fig. 1. The conventional vortex circulation in $2 \mathrm{D}$ is given by

$$
\Gamma=\oint_{C} b \mathrm{~d} C=\int_{A_{1}} \omega \mathrm{d} A_{1},
$$

where $b$ denotes a velocity component aligned along the vortex boundary $C$, vorticity $\omega$ is integrated over the vortex cross section $A_{1}$ bounded by $C$. The vortex boundary $C$ can be defined by the requirement of zero vorticity contour - this is physically the most natural choice of threshold inside which the vorticity magnitude is non-zero everywhere.

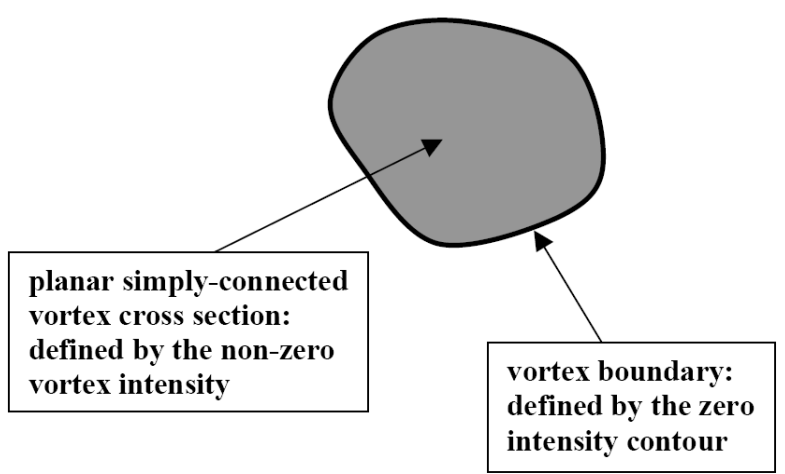

Fig. 1. Generally defined vortex cross section.

Obr. 1. Všeobecně definovaný řez vírem.

The fact that vorticity absorbs the local shearing effects has motivated a novel approach to vortex identification (Kolár, 2007) which is based on purely kinematic grounds, namely on the triple decomposition of the local relative motion near a point (TDM). Vorticity is decomposed into two parts, shear vorticity and residual vorticity. The residual vorticity is associated with the local residual rigid-body rotation near a point obtained after the extraction of an effective pure shearing motion. Geometrical interpretation of the residual vorticity (denoted below as $\omega_{\mathrm{RES}}$ ) is particularly simple in 2D and quasi-2D problems.

Focusing on the flow kinematics near a point, the residual vorticity is interpreted in terms of the leastabsolute-value angular velocity of all line segments, within the flow plane, going through the given point (Kolár , 2007, 2008). Consequently, the global motion of an ideal axisymmetric vortex in concentric shearing layers is interpreted in terms of the virtual superposition of distinguished local relative motions near a point as shown in Fig. 2 (for clarity including a circular translation). It should be emphasized that this superimposing construction is of a non-destructive nature (shear vorticity and residual vorticity are of the same sign) and is applicable to infinitesimal motional changes only.

The circulation based on the residual vorticity, labelled "residual circulation", can be introduced in a similar manner as the conventional circulation. The residual circulation reads

$\Gamma_{\mathrm{RES}}=\int_{A_{2}} \omega_{\mathrm{RES}} \mathrm{d} A_{2}$,

where $\omega_{\text {RES }}$ is given by subtracting the shear vorticity $\omega_{\mathrm{SH}}$ from the (total) vorticity $\omega$. The (nonzero) residual vorticity is basically the simplest measure of the dominance of planar vorticity magnitude over planar strain-rate magnitude. For the planar velocity-gradient tensor of the form $\left(\begin{array}{cc}u_{x} & u_{y} \\ v_{x} & -u_{x}\end{array}\right)-$ alternatively represented by $\left(\begin{array}{ll}s / 2 & -\omega / 2 \\ \omega / 2 & -s / 2\end{array}\right)^{\substack{\text { PRINCIPAL } \\ \text { AXES }}}$ where $s$ denotes (twice) the 2D principal rate of strain and $\omega$ is the 2D vorticity - it follows (Kolár , 2007)

$\omega=v_{x}-u_{y}$,

$|s|=\sqrt{4 u_{x}^{2}+\left(u_{y}+v_{x}\right)^{2}}$,

$\omega_{\mathrm{RES}}=\omega-\omega_{\mathrm{SH}}=(\operatorname{sgn} \omega)[|\omega|-|s|]$

for $|\omega| \geq|s|$, 


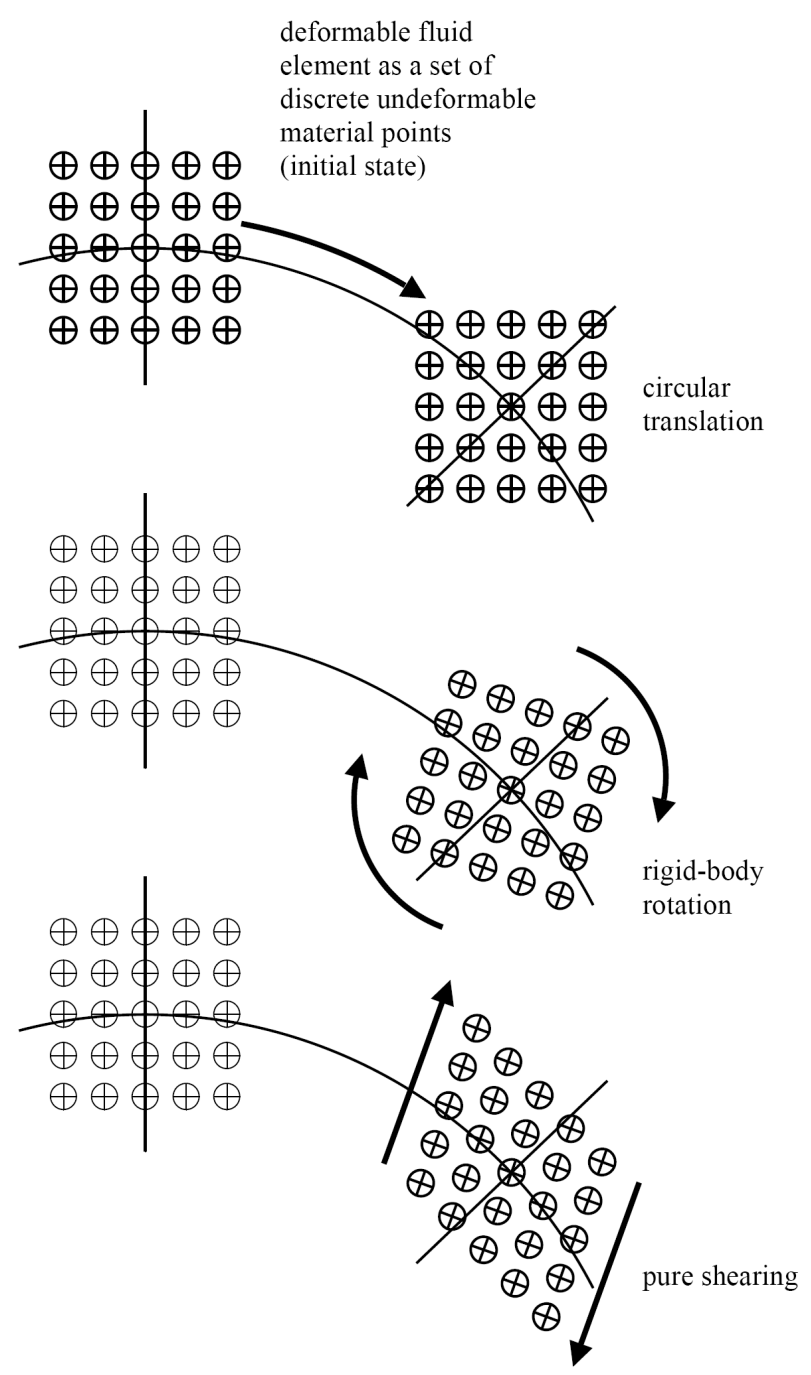

Fig. 2. Virtual infinitesimal motional changes of the fluid element within an ideally axisymmetric vortex (each change at the final stage), according to Kolár (2007).

Obr. 2. Virtuální infinitesimální pohybové změny elementu tekutiny uvnitř ideálně osově symetrického víru (každá změna v konečném stavu), podle lit. Kolár (2007).

$\omega_{\mathrm{RES}}=0$ for $|\omega| \leq|s|$.

The vortex cross sections in (1) and (2) are generally different, $A_{1} \neq A_{2}$, as the vortex-boundary definition is naturally subjected to the local vortex intensity adopted: the condition of zero intensity at the boundary is required, see Fig. 1.

Note that, unlike $\Gamma$ which is always non-zero for a simple shear, $\Gamma_{\text {RES }}$ is always zero for a simple shear as desired for vortex-identification criterion.

A third model of the vortex strength is based on the local swirling-strength parameter of the vortexidentification method of Zhou et al. (1999). The local vortex intensity, called swirling strength, is proposed in terms of the angular frequency of revolutions of spiralling streamlines in a local reference frame moving with the examined point. In $2 \mathrm{D}$, this frequency is just a half of $\sqrt{\omega^{2}-s^{2}}$ under the corresponding vortex-identification condition $|\omega|>|s|$. In view of the quantitatively same vortex-strength value for a rigid-body rotation evaluated by all the three considered vortex-strength models, it follows for the third model

$$
\Gamma_{\mathrm{Z}}=\int_{A_{3}} \sqrt{\omega^{2}-s^{2}} \mathrm{~d} A_{3} .
$$

The boundary of the second vortex-strength model $\Gamma_{\text {RES }}$ coincides with that of the third model $\Gamma_{\mathrm{Z}}$, and is found by the same condition $|s|=|\omega|$. Consequently, the corresponding vortex crosssections are identical, $A_{2}=A_{3}$.

\section{Application of different vortex-strength models to the unsteady Taylor vortex}

From the simple conversion between Cartesian and polar coordinates and the relations (3), (4) we obtain for an arbitrary unsteady axisymmetric distribution of tangential velocity $V \equiv V(r, t) \quad(r$ is radius, $r=\sqrt{x^{2}+y^{2}}$, and $t$ denotes time)

$\omega=\frac{1}{r} \frac{\partial}{\partial r}(r V)=\frac{\partial V}{\partial r}+\frac{V}{r}$,

$|s|=\left|\frac{\partial V}{\partial r}-\frac{V}{r}\right|$.

The vortex region is identified in Kolár̆ (2007) by the condition of non-zero residual vorticity, that is, in $2 \mathrm{D}$, by the condition $|\omega|>|s|$ which can be rewritten as (monotonous decay of vorticity with increasing radius is naturally assumed, at least inside the vortex region)

$\left|\frac{\partial V}{\partial r}+\frac{V}{r}\right|>\left|\frac{\partial V}{\partial r}-\frac{V}{r}\right|$.

Consequently, $\partial V / \partial r$ and $V / r$ must have the same sign inside the vortex region. The vortex boundary is found by $\omega_{\text {RES }}=0$, or equivalently, by $\partial V / \partial r=0$. Hence, the vortex radius is the radius at which the tangential velocity is a maximum what is just the conventional definition of the circular vortex core (Green, 1995). 
From (5) and (8)-(10), the final expression for non-zero $\omega_{\text {RES }}$ (i.e. for the vortex region) reads

$$
\omega_{\mathrm{RES}}=2(\operatorname{sgn} \omega)\left|\frac{\partial V}{\partial r}\right| \text { for }|\omega|>|s| .
$$

The unsteady Taylor vortex (e.g. Panton, 1984) centred at $(0,0)$ is described in polar coordinates by the tangential velocity distribution $V(r, t)$ of the following form

$$
V=\frac{A r}{t^{2}} \exp \left(-\frac{B r^{2}}{t}\right),
$$

where $A, B$ are positive physical parameters related to angular momentum and/or viscosity. Using (8), (11) and (12), the unsteady vortex boundary in terms of $\omega$ and $\omega_{\text {RES }}$ can be easily determined from the conditions $\omega=0$ and $\omega_{\mathrm{RES}}=0$ (i.e. $\partial V / \partial r=0)$, respectively,

$R_{1}(\equiv$ boundary radius at which $\omega=0)=\sqrt{\frac{t}{B}}$,

$R_{2}\left(\equiv\right.$ boundary radius at which $\left.\omega_{\mathrm{RES}}=0\right)=\sqrt{\frac{t}{2 B}}$.

The circulation - the vortex strength based on $\omega$ - is obtained from (8), (12) and (13) after a short calculation (e denotes the base of the natural logarithm)

$$
\Gamma=2 \pi R_{1} \cdot V\left(R_{1}\right)=\frac{2 \pi A}{B} \cdot \frac{1}{\mathrm{e}} \cdot \frac{1}{t} .
$$

The residual circulation - the vortex strength based on $\omega_{\text {RES }}$ - is determined from (11), (12) and (14) as a similar hyperbolic function of time as in the case of $\Gamma$

$$
\begin{aligned}
\Gamma_{\mathrm{RES}} & =4 \pi R_{2} \cdot V\left(R_{2}\right)-4 \pi \int_{0}^{R_{2}} V \mathrm{~d} r= \\
& =\frac{2 \pi A}{B} \cdot \frac{2-\sqrt{\mathrm{e}}}{\sqrt{\mathrm{e}}} \cdot \frac{1}{t} .
\end{aligned}
$$

From (15) and (16) it follows

$\frac{\Gamma_{\mathrm{RES}}}{\Gamma}=2 \sqrt{\mathrm{e}}-\mathrm{e} \approx 0.579$.

This result that $\Gamma_{\mathrm{RES}}$ is less than sixty percent of $\Gamma$ is valid for the unsteady Taylor vortex of the velocity distribution (12). The same apparently holds for the ratio of the vortex-strength decay rates $\mathrm{d} \Gamma_{\mathrm{RES}} / \mathrm{d} t$ and $\mathrm{d} \Gamma / \mathrm{d} t$. Recall that $\Gamma_{\mathrm{RES}}-$ unlike $\Gamma$ - does not absorb any local shearing effects near a point and is based on the local rigid-body rotation only (cf. Fig. 2). It is easy to verify that for the limiting case of rigid-body rotation of a circular fluid region we obtain $\Gamma_{\mathrm{RES}} / \Gamma=1$, as expected.

The vortex region defined by $\omega_{\mathrm{RES}}$ is the same as the region defined by the swirling-strength parameter $\sqrt{\omega^{2}-s^{2}}$ (see Section 2). Both these regions are characterized by $|\omega|>|s|$ and bounded by the condition $|s|=|\omega|$. However, with the exception of the rigid-body rotation of a circular fluid region, both these regions are smaller than the $\omega$-based vortex region bounded by the condition $\omega=0$.

Denoting $\varepsilon=|s| /|\omega|$, we have

$$
0<1-\varepsilon<\sqrt{(1-\varepsilon)(1+\varepsilon)}<1 \text { for } 0<\varepsilon<1 \text {. }
$$

From here the following upper and lower estimates for the third vortex-strength model $\Gamma_{\mathrm{z}}$ given by (7) can be drawn

$$
\Gamma_{\mathrm{RES}}<\Gamma_{\mathrm{Z}}<\Gamma \text {. }
$$

This result is not surprising as the swirlingstrength parameter, though somewhat better for vortex-identification purposes than vorticity, still remains a strongly shear-absorbing quantity (Kolár 2007). Consequently, at a given instant of time, the values of $\Gamma_{\mathrm{Z}}$ are higher than those of $\Gamma_{\mathrm{RES}}$, though the vortex region is the same for both different underlying non-zero vortex intensities.

\section{Concluding remarks}

As shown above in 2D, different vortex-strength models can be derived on the basis of different local vortex intensities. The vortex region, vortex boundary and, consequently, the (integral) vortex strength are directly dependent on the choice of a local vortex intensity. The vortex strength is calculated for the planar simply-connected vortex cross section defined by the non-zero vortex intensity and bounded by the zero intensity contour (Fig. 1).

Three vortex-strength models are discussed and compared by examining the unsteady Taylor vortex. These models include the well-known conventional circulation $\Gamma$, the so-called residual circula- 
tion $\Gamma_{\mathrm{RES}}$ based on the residual vorticity (Kolár, 2007), and the integral $\Gamma_{\mathrm{Z}}$ of the local swirlingstrength parameter (Zhou et al., 1999). The outcome of these models naturally differs, even for an ideally axisymmetric vortex. For the unsteady Taylor vortex flow, $\Gamma$ and $\Gamma_{\mathrm{RES}}$ are analytically expressed by (15) and (16) as hyperbolic functions of time, and the integral $\Gamma_{\mathrm{z}}$ is estimated by (19).

Unlike $\Gamma_{\mathrm{RES}}$, both $\Gamma$ and $\Gamma_{\mathrm{z}}$ are shear-biased vortex-strength models. However, for the special case of a simple shear, $\Gamma$ is always non-zero whereas $\Gamma_{\mathrm{RES}}$ and $\Gamma_{\mathrm{z}}$ are always zero as desired for true vortex characteristics. In this regard, $\Gamma_{\mathrm{Z}}$ is certainly better than $\Gamma$. The integral $\Gamma_{\mathrm{z}}$ is derived from the local vortex intensity $\sqrt{\omega^{2}-s^{2}}$. As pointed out in Kolár $(2007)$, the quantity $\omega^{2}-s^{2}$ exhibits a strong inherent bias towards $[|\omega|+|s|]$ while employed in vortex identification. This fact makes $\Gamma_{\mathrm{z}}$ a shear-biased vortex-strength model though generally having lower values than $\Gamma$ which is apparently more absorbing a local shear than $\Gamma_{\mathrm{z}}$ (see also (19)). Summing up, in the description of vortex strength, there are strong reasons to prefer the residual circulation $\Gamma_{\mathrm{RES}}$ to the conventional circulation $\Gamma$ and the integral $\Gamma_{\mathrm{z}}$. Note that the quantity $\Gamma_{\mathrm{RES}}$ has already proved its usefulness for the description of single and twin jets in crossflow (Kolár and Savory, 2007). For different nozzle arrangements, an almost universal behaviour of $\Gamma_{\mathrm{RES}}$ has been revealed for the resulting secondary-flow counter-rotating vortex pair.

Acknowledgements. This work was supported by the Grant Agency of the Acad. of Sci. of the Czech Rep. through grant IAA200600801, and by the Acad. of Sci. of the Czech Rep. through AV0Z20600510.

\section{List of symbols}

A - parameter of the unsteady Taylor vortex according to (12) $[\mathrm{T}]$,

$A_{1} \quad-$ vortex region defined by $\omega\left[\mathrm{L}^{2}\right]$,

$A_{2} \quad-$ vortex region defined by $\omega_{\mathrm{RES}}\left[\mathrm{L}^{2}\right]$,

$A_{3} \quad-$ vortex region defined by $\sqrt{\omega^{2}-s^{2}}\left[\mathrm{~L}^{2}\right]$,

$b \quad$ - velocity component aligned along the vortex boundary $C\left[\mathrm{~L} \mathrm{~T}^{-1}\right]$,
$B$

C - vortex boundary [L],

e $\quad-$ base of the natural logarithm, Euler's number [-],

$r \quad$ - radius [L],

$R_{1} \quad$ - boundary radius at which $\omega=0$ [L],

$R_{2} \quad$ - boundary radius at which $\omega_{\mathrm{RES}}=0[\mathrm{~L}]$,

$s \quad-$ (twice) principal rate of strain (in 2D) $\left[\mathrm{T}^{-1}\right]$,

$t \quad-$ time [T],

$u, v \quad$ - components of the velocity vector (in $2 \mathrm{D}$ ) $\left[\mathrm{L} \mathrm{T}^{-1}\right]$,

$V \quad$ - tangential velocity $\left[\mathrm{L} \mathrm{T}^{-1}\right]$,

$x, y \quad$ - Cartesian coordinates (in 2D) [L],

$x, y$ - subscripts stand for spatial partial derivatives,

$\Gamma \quad$ - surface integral of $\omega\left[\mathrm{L}^{2} \mathrm{~T}^{-1}\right]$

$\Gamma_{\text {RES }}$ - surface integral of $\omega_{\text {RES }}\left[\mathrm{L}^{2} \mathrm{~T}^{-1}\right]$,

$\Gamma_{\mathrm{Z}} \quad$ - surface integral of $\sqrt{\omega^{2}-s^{2}}\left[\mathrm{~L}^{2} \mathrm{~T}^{-1}\right]$,

$\varepsilon \quad-$ ratio, $\varepsilon=|s| /|\omega|[-]$,

$\omega \quad-$ vorticity (in 2D) $\left[\mathrm{T}^{-1}\right]$,

$\omega_{\text {RES }}-$ residual vorticity (in $2 \mathrm{D}$ ) $\left[\mathrm{T}^{-1}\right]$,

$\omega_{\mathrm{SH}}-$ shear vorticity (in $\left.2 \mathrm{D}\right)\left[\mathrm{T}^{-1}\right]$.

\section{REFERENCES}

BATCHELOR G.K., 1967: An Introduction to Fluid Dynamics. Cambridge University Press.

GREEN S.I., 1995: Fluid Vortices. Kluwer.

KOLÁŘ V., 2007: Vortex identification: New requirements and limitations. Int. J. Heat Fluid Flow, 28, 638-652.

KOLÁŘ V., 2008: On the relationship between a vortex and vorticity. Abstracts of the IUTAM Symposium "150 Years of Vortex Dynamics", Lyngby-Copenhagen (Denmark), http://www.fluid.dtu.dk/English/Symposia/IUTAM_sympos ium/Program.aspx

KOLÁŘ V., SAVORY E., 2007: Dominant flow features of twin jets and plumes in crossflow. J. Wind Eng. Ind. Aerodyn., 95, 1199-1215.

PANTON R.L., 1984: Incompressible Flow. Wiley.

SAFFMAN P.G., 1992: Vortex Dynamics. Cambridge University Press.

ZHOU J., ADRIAN R.J., BALACHANDAR S., KENDALL T.M., 1999: Mechanisms for generating coherent packets of hairpin vortices in channel flow. J. Fluid Mech., 387, 353$-396$.

Received 12 December 2008

Accepted 14 October 2009

\section{POZNÁMKA O INTEGRÁLNÍ SÍLE VÍRU}

\section{Václav Kolář}

Integrální síla víru je počitána obvykle jako cirkulace podél hranice víru nebo, ekvivalentně podle Greenovy věty, jako plošný integrál viŕivosti přes příčný rovinný řez vírem. $V$ př́padě interakce víru se smykem je však lokální efekt libovolného "superponovaného smyku" plně absorbován viŕivostí, což činí z cirkulace smykově zkreslenou vírovou charakteristiku. Ve 2D je ukázáno, že různé modely síly víru lze odvodit na základě různých 
lokálních intenzit víru. Tyto integrální charakteristiky jsou počítány přes příčný rovinný řez vírem, který je na hranici definován podmínkou nulové intenzity víru. Oblast víru a hranice víru př́mo podléhají volbě lokální intenzity víru.

Na podkladě zkoumání nestacionárního Taylorova víru (12) jsou porovnány a diskutovány tři různé modely síly víru. Tyto modely zahrnují konvenční cirkulaci $\Gamma$, tzv. reziduální cirkulaci $\Gamma_{\mathrm{RES}}$, která je založena na reziduální vírivosti (Kolář, 2007), a integrál $\Gamma_{Z}$ lokálního parametru vírivé síly (Zhou et al., 1999). Výsledky těchto modelů se přirozeně liší, dokonce i pro ideálně osově symetrický vír.

Cirkulace $\Gamma$ a reziduální cirkulace $\Gamma_{\mathrm{RES}}$ jsou analyticky vyjádřeny pro nestacionární Taylorův vír (12) jako hyperbolické funkce času vztahy (15) a (16). Pro velikost integrálu $\Gamma_{\mathrm{Z}}$ je stanoven odhad (19).

Na rozdíl od $\Gamma_{\mathrm{RES}}$, jak $\Gamma$ tak $\Gamma_{\mathrm{Z}}$ jsou smykově zkreslené modely síly víru. Pro speciální př́pad prostého smyku je však $\Gamma$ vždycky nenulové, zatímco $\Gamma_{\mathrm{RES}}$ a $\Gamma_{\mathrm{Z}}$ jsou vždycky nulové, jak je žádoucí pro správné vírové charakteristiky. V tomto ohledu je $\Gamma_{\mathrm{Z}}$ lepší než $\Gamma$. Integrál $\Gamma_{Z}$ je odvozen z lokální intenzity víru $\sqrt{\omega^{2}-s^{2}}$. Jak je zdůrazněno v práci Kolár̆ (2007), veličina $\omega^{2}-s^{2}$ vykazuje při užití pro vírovou identifikaci silné zkreslení směrem k $[|\omega|+|s|]$. Tato skutečnost nevyhnutelně činí z integrálu $\Gamma_{\mathrm{Z}}$ smykově zkreslený model síly víru, ačkoliv obecně dosahuje nižších hodnot než cirkulace $\Gamma$, která absorbuje lokální smyk výrazněji než $\Gamma_{Z}$ (viz také (19)). Můžeme shrnout, že existují pádné důvody preferovat při popisu integrální síly víru reziduální cirkulaci $\Gamma_{\mathrm{RES}}$ před konvenční cirkulací $\Gamma$ a integrálem $\Gamma_{\mathrm{Z}}$.

\section{Seznam symbolì}

A - parametr nestacionárního Taylorova víru podle (12) [T],

$A_{1} \quad$ - oblast víru definovaná pomocí $\omega\left[\mathrm{L}^{2}\right]$,

$A_{2} \quad$ - oblast víru definovaná pomocí $\omega_{\mathrm{RES}}\left[\mathrm{L}^{2}\right]$,

$A_{3} \quad$ oblast víru definovaná pomocí $\sqrt{\omega^{2}-s^{2}}\left[\mathrm{~L}^{2}\right]$,

$b \quad$ - složka rychlosti podél hranice víru $C\left[\mathrm{~L} \mathrm{~T}^{-1}\right]$,

$B \quad$ - parametr nestacionárního Taylorova víru podle (12) $\left[\mathrm{L}^{-2} \mathrm{~T}\right]$,

C - hranice víru [L],

e - základ přirozených logaritmů, Eulerovo číslo [-],

$r$ - rádius [L],

$R_{1} \quad-$ hraniční rádius, pro který $\omega=0[\mathrm{~L}]$,

$R_{2} \quad$ - hraniční rádius, pro který $\omega_{\mathrm{RES}}=0[\mathrm{~L}]$,

$s \quad-$ (dvakrát) hlavní rychlost deformace (ve 2D) $\left[\mathrm{T}^{-1}\right]$,

$t \quad-$ čas [T],

$u, v \quad$ - složky vektoru rychlosti (ve $2 \mathrm{D})\left[\mathrm{L} \mathrm{T}^{-1}\right]$,

$V \quad$ - tangenciální rychlost $\left[\mathrm{L} \mathrm{T}^{-1}\right]$,

$x, y \quad$ - kartézské souřadnice (ve 2D) [L],

$x, y-$ dolní indexy označující prostorové parciální derivace,

$\Gamma \quad$ - plošný integrál přes $\omega\left[\mathrm{L}^{2} \mathrm{~T}^{-1}\right]$,

$\Gamma_{\text {RES }}-$ plošný integrál přes $\omega_{\text {RES }}\left[\mathrm{L}^{2} \mathrm{~T}^{-1}\right]$,

$\Gamma_{\mathrm{Z}} \quad$ - plošný integrál přes $\sqrt{\omega^{2}-s^{2}}\left[\mathrm{~L}^{2} \mathrm{~T}^{-1}\right]$,

$\varepsilon \quad-$ poměr, $\varepsilon=|s| /|\omega|[-]$,

$\omega-$ viŕrivost (ve $2 \mathrm{D}$ ) $\left[\mathrm{T}^{-1}\right]$

$\omega_{\text {RES }}-$ reziduální vírivost (ve $\left.2 \mathrm{D}\right)\left[\mathrm{T}^{-1}\right]$,

$\omega_{\mathrm{SH}}-$ smyková vírivost (ve $\left.2 \mathrm{D}\right)\left[\mathrm{T}^{-1}\right]$. 